\title{
The Development of Flash-Based Media in Project Based Learning for English Subject to Increase Students' Motivation and Achievement at Senior High School
}

\author{
Trisyagil $^{1 \bowtie}$, Farid Ahmadi $^{2} \&$ Kustiono $^{2}$ \\ ${ }^{1}$ Universitas Swadaya Gunung Jati, Cirebon, Jawa Barat, Indonesia \\ ${ }^{2}$ Primary Teacher Education, Universitas Negeri Semarang, Indonesia \\ ${ }^{3}$ Education Technology, Universitas Negeri Semarang, Indonesia
}

\begin{abstract}
Article Info
History Articles

Received:

November 2019

Accepted:

December 2019

Published:

November 2020

Keywords:

english learning,

flash,

project based learning

DOI

https://doi.org/10.15294

/ijcet.v9i2.36301

Abstract

The use of technology-based media increases students' motivation and learning effectivity in the classroom. This research aims to develop, to examine the appropriateness and the effectivity of flash-based media at Senior High School. This development research uses the ADDIE model. Based on the research result, the score of validity trials from the material expert is 72 , the score from the media expert is 58 and from the practitioner expert is 75 . The assessment from the material, media and practitioner expert show that flash-based media is in the appropriate category. Effectiveness test of the flash-based media development is through the testing of hypothesis, the data shows that for both experimental and controlled class in pre-test and post-test, the score is Sig. (2-tailed) $0.000<0.05$, and the score of the students' motivation in learning for pre-test and post-test in both experimental and controlled is Sig. (2-tailed) $0.000<0.05$. It means that the flash-based media increases students' motivation and achievement in the learning process. This research result supports the theories of technology learning, especially for the development of learning aids and media for English subject.
\end{abstract}




\section{INTRODUCTION}

Education is the effort to increase the human resource quality (Nur, 2019). Curriculum is the crucial component to realize the objective of the education (Farchan, 2019). To support the successful achievement of education in Indonesia, the government developed the curriculum 2013 (Subekti, 2016). Qualified education supports the formation of intelligent, successful and knowledgeable youth to compete in this global era.

curriculum 2013 is the new curriculum focusing on the scientific approach (Budiani, 2017). It is recently implemented in Indonesia as the development of school-based curriculum (KTSP, 2006) (Kosam, 2018). In 2014/2015, educational institution simultaneously implemented the curriculum 2013 as the improvement of the school-based curriculum (Alawiyah, 2014). This is one of the government effort to achieve the objective of education.

According to (Priyatni, 2014) the recommended method applied in curriculum 2013 is scientific approach which is enriched with discovery learning. The project-based learning is a model of learning using the project (activity) as the main process of teaching and learning (Lasauskiene, 2015). This project helps students to discover the new concepts, new experience and to increase the students' creativity to solve the problems as well as to make the new products (Jakab, 2019). This project is the innovative learning that involves the project work where the students independently do their work.

The process of English learning has three main objectives; they are developing the spoken and written communication skill in English (listening, speaking, reading and writing), increasing the awareness of the importance of language learning and the importance of English as the foreign language to learn (Megawati, 2016). The students' difficulties in learning and understanding english is especially in writing descriptive text as the basic skill of students' writing. (Palupi, 2017). The aids or media of learning ease the students in learning the abstract material to be the concrete one (Chae, 2015). The media helps the students in understanding and to make the process of teaching and learning become effective and efficient. The use of media in the process of teaching and learning also increases the students' interest and motivation (Firdaus, 2012). One of the media developed for learning is the flash-based media. This media improves the students' achievement (Hutomo, 2015). The research conducted by (Rahmaibu, 2016) shows that the multimedia-based learning using flash increases the students' achievement. The appropriate media maximizes the process of teaching and learning, so that the learning objectives would be better achieved.

The development of android-based learning media using flash application increases students' achievement (Muyaroah, 2017). According to (Permana, 2015) the development of problem-based learning using flash improves the students' achivement. The development of flash focuses on the result of the students' achievement and implemented in the problembased learning.

Seeing that the development of flash-based media has not been impelemented in the projectbased learning, and focuses on the resutl of learning, so that, it is needed to develope the flash-based in the project-based learning for Eglish subject to increase students' motivation and achievement at Senior High School. This research purposes on the development, test of the appropriatness and effectiveness of the flashbased media at Senior High School. Through this development, the research is expected to give the contribution in the project-based learning, especially in developing the teaching aids and media for English learning.

\section{METHODS}

The design of this research uses the ADDIE development research. The ADDIE model is the term used to describe the systematic approach to develop the learning (Molenda, 2003). The population of the research is SMA Negeri 1 Susukan. This research was started in January, $3^{\text {rd }}-7$ th 2018 . The determination of the 
sample uses the random sample technique. The following table shows the sample of the research:

Table 1. Research in Experimental and Controlled Class

\begin{tabular}{lcl}
\hline Sample of the research & Class & \multicolumn{1}{c}{ Students } \\
\hline \multirow{2}{*}{ Experimental } & X IPA 1 & 25 Students \\
\multirow{3}{*}{ Controlled } & X IPA 2 & 25 Students \\
& X IPS 1 & 25 Students \\
& X IPS 2 & 25 Students \\
& & 100 Students \\
\hline
\end{tabular}

The techniques of collecting data in this research use the observation, test, questionnaire and documentation. Observation is to analyze the needs of learning aids or media. Test, in the form of multiple choice is to know the effectivity of flash-based media which has been developed. Questionnaire is to measure the students' motivation. Documentation is to get the direct data from the place of the research.

Table 2. Normality Test for Students' Motivation and Students' Achievement

\begin{tabular}{cllcccc}
\hline Variable & Class & Test & $\mathrm{N}$ & Sig. (2-tailed) & Decision & Conclusion \\
\hline Learning motivation & Experiment & Pre-test & 50 & .101 & $H_{0}$ accepted & Normal \\
& & Post-test & 50 & .096 & $H_{0}$ accepted & Normal \\
& controlled & Pre-test & 50 & .173 & $H_{0}$ accepted & Normal \\
& & Post-test & 50 & .106 & $H_{0}$ accepted & Normal \\
Achievement & \multirow{2}{*}{ Experiment } & Pre-test & 50 & .159 & $H_{0}$ accepted & Normal \\
& & Post-test & 50 & .200 & $H_{0}$ accepted & Normal \\
& \multirow{2}{*}{ controlled } & Pre-test & 50 & .106 & $H_{0}$ accepted & Normal \\
& & Post-test & 50 & .143 & $H_{0}$ accepted & Normal \\
\hline
\end{tabular}

Normality test is to know the distribution of the data. This is the criteria of decision making: if the score of Sig. is $<0.05$, it means that the data are not normal, if the score of Sig. is $>0.05$, it means that the data are normal.

Based on the table 2, it shows that the result score of normality test of the students' motivation and achievement for the experimental class and controlled is Sig. $>0.05$. So, it can be concluded that the data for the experimental and controlled class distribute normally.

Homogeneity test uses the Lavene' test. The significance of the score on the Lavene test using the level of significance $5 \%(\alpha=0.05)$. The criteria of decision making: if the score of Sig. is $>0.05$ so that the $H_{0}$ is accepted, if the score of Sig. is $<0.05$ it means that the $H_{0}$ is rejected.

Table 3. Homogeneity Test for Students' Motivation and Students' Achievement

\begin{tabular}{lrccc}
\hline \multicolumn{1}{c}{ Variable } & Levene statistic & $\mathrm{df}_{1}$ & $\mathrm{df}_{2}$ & Sig. \\
\hline Learning motivation & 2.374 & 1 & 98 & .127 \\
Achievement & .986 & 1 & 98 & .323 \\
\hline
\end{tabular}

Based on the table 3, it shows that the result of homogeneity test for the students' motivation and achievement is Sig. $>0.05$. It can be decided that $H_{0}$ is accepted and the variance of learning motivation data is homogenous.

\section{RESULTS AND DISCUSSION}

\section{The Development of Media}

The project-based learning for English subject using flash-based is the product of development research through the stage of need analysis. It is the analysis of the media used in the process of teaching and learning. The need analysis is aimed at teachers and students. This observation stage is to establish the material and the design of media which would be developed and appropriately used. In this stage, the result of curriculum analysis is descriptive text material related to the syllabus of the tenth grade of Senior High School and to make the presented material relates to the standard competency and basic competency.

The final result for the development stage of flash-based learning media which aims to improve students' motivation and achievement can be seen in the following picture.

Picture 1 shows that the media is started with a simple intro of a loading animation with a background image. 


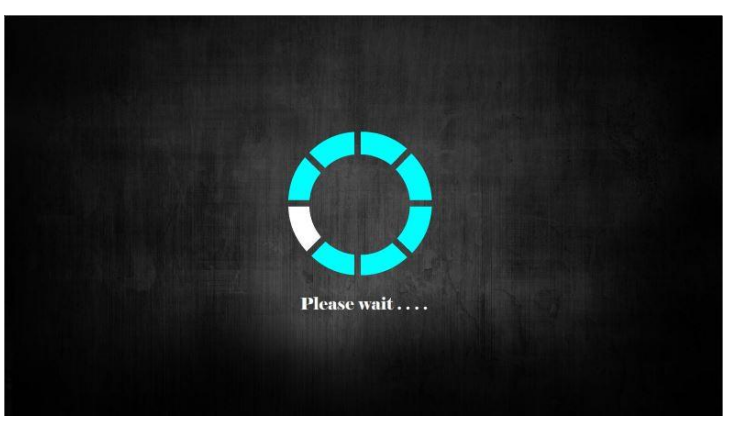

Picture 1. Opening Display

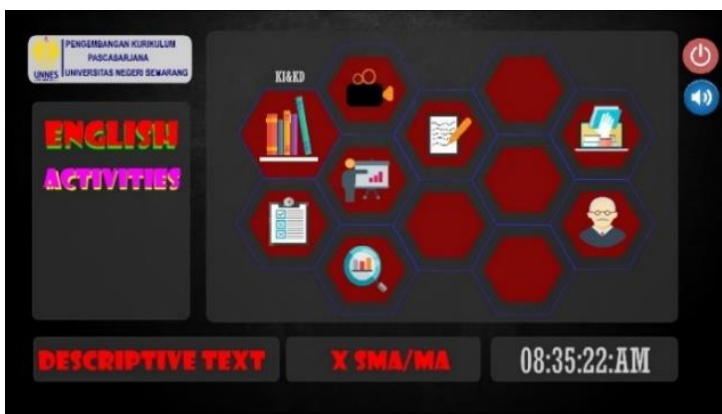

Picture 2. Main Course

Picture 2, there is the main course of the flash-based media that consists of several menus or courses in the middle of screen, namely KI-KD (main competency-basic competency), Lesson, Exercise, Practice, References, Video of Education, Writing and Profile menus.

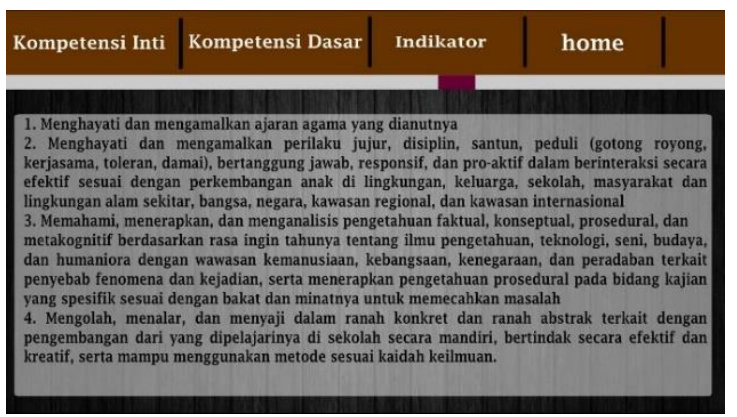

Picture 3. KI \& KD Menu

Picture 3 is KI\&KD menu. In this menu, there are main competency and basic competency, as well as the indicators to achieve in the process of learning.



Picture 4. Practice Menu

In the practice menu, it presents some exercises for the students about writing the descriptive text.



Picture 5. Video Menu

Picture 5 shows the video of education menu. In this menu, there are various videos related to the material.



Picture 6. Lesson Menu

Picture 6 is Lesson Menu. In this menu, it contains several material of descriptive text which will be delivered to the students. This menu presents the definition, aim, generic structure, language feature, example, home. 




Picture 7. References Menu

Picture 7 is feferences menu. It displays some references taken by the researcher in developing the material to deliver in the process of teaching and learning.



Picture 8. Exercise Menu

Picture 8 is exercise Menu. It contains the learning evaluation which is presented in the form of multiple choice.

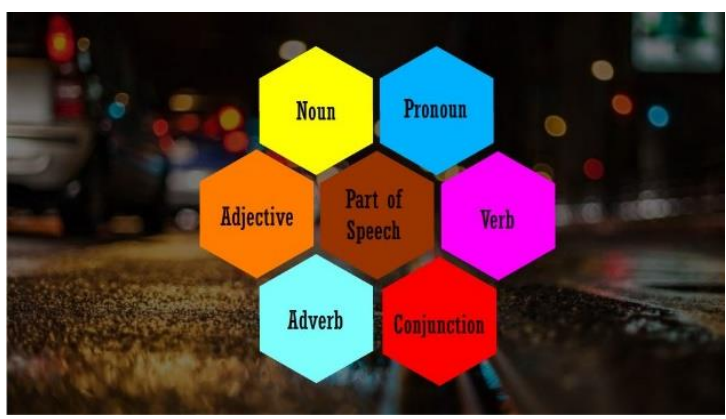

Picture 9. Writing Skill Menu

Picture 9 is the writing skill menu which contains the material that support the descriptive text material.



Picture 10. Profile Menu

Picture 10 is the profile menu. This menu tells about the profile of the developer which is presented in the form of photo and biography.

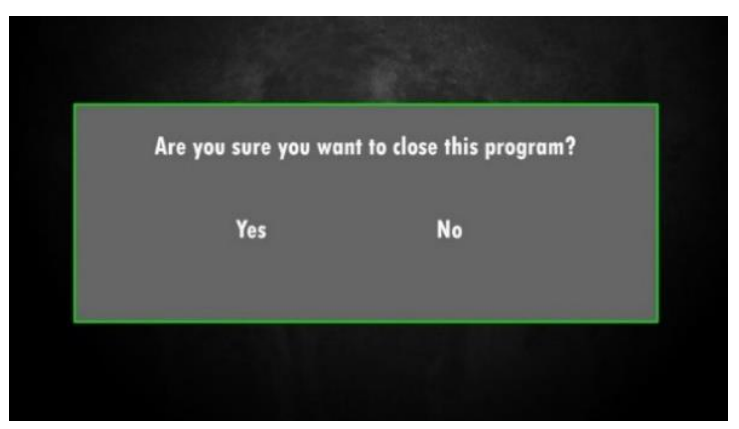

Picture 11. Exit Menu

Picture 11 is the exit menu. There are two choices in this menu, namely yes and no. 'Yes' means to close the menu and 'No' means to be back to the main menu.

The development of flash-based learning media includes the result of the identification of the potency and problems (Listantia, 2015). The development of a certain product is through the observation and interview from the subjects of the research.

The development of flash-based media is based on the need analysis. This analysis is in the form of questionnaire given to the teachers and students. The result shows that the both teachers and students need the learning media which are interesting, easy, and efficient.

The result of need analysis from teachers and students shows that the flash-based media is important to use as the learning media for the English subject. It is in line with the research conducted by (Priyadana, 2015) the development of flash-based media is more interesting, interactive, effective and efficient. The process of 
teaching and learning would be more effective and efficient through the use of media, it is because the learning by using media can be everywhere and anywhere. It also accommodates students who are difficult to understand the presented material. From this view, it obviously shows that the current research is relevant with the previous research.

\section{The Appropriateness of the Media}

The learning media which has been obtained then it is validated by the team of the experts. This validation by the expert is to get their comments, suggestion, and agreement. So that, the first product design would be appropriate to use in the process of teaching learning. Those experts are the expert of media, material and practitioner. Each expert gives the score and value from the questionnaire. The following table will show the score or value from those experts.

Table 4. Result of validation from the experts

\begin{tabular}{lcl}
\hline \multicolumn{1}{c}{ Validator } & Score & Criteria \\
\hline Media & 58 & Valid \\
Material & 75 & Very Valid \\
Practitioner & 72 & Very Valid \\
\hline
\end{tabular}

The development of learning media through the finishing stage is after the team of the experts give the validation and suggestion.

Small group test is to know the appropriateness of the media which will be developed by the researcher before it is implemented in the bigger group.

The researcher tests the media at the tenth grade which is not a sample of the research. The table below will display the result of the trial test.

Table 5. Result of the Small Group

\begin{tabular}{ccc}
\hline Class & Score & Criteria \\
\hline $\mathrm{X}$ & 77.2 & Very Valid \\
\hline
\end{tabular}

The next stage, the media been evaluated by the material, media and practitioner experts and after the small group test should be revised based on the suggestion given by the experts, and then it is implemented in the experimental class with a big scale.
The result of this research is in the form of the score obtained by using test to know the students' competency achievement after using the flash-based media and questionnaire to measure students' motivation.

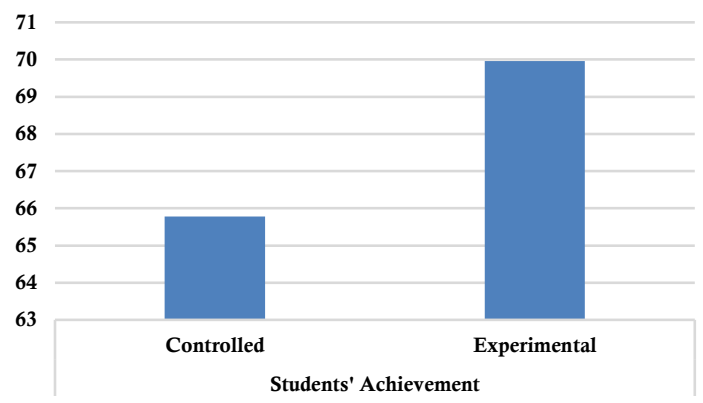

Picture 12. The Comparison of The Mean Score of Students' Motivation

Based on the picture 12, it shows that the mean score of the students' motivation in the experimental class is higher than the controlled class, so it can be concluded that the learning process using flash-based media for English subject improves the students' motivation.

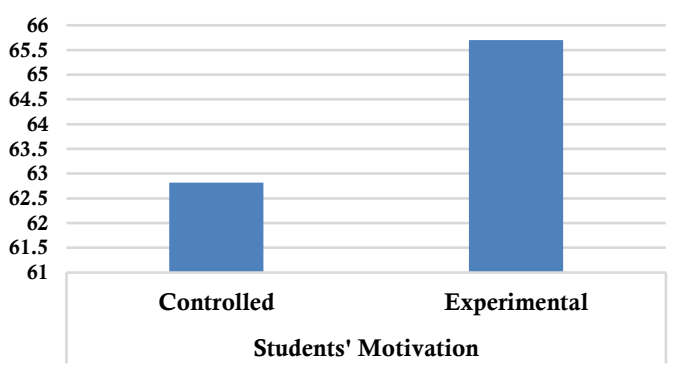

Picture 13. The Comparison of Mean Score of The Students' Achievement

Based on the picture 13, it shows that the mean score of the students' achievement in the experimental class is higher than the controlled class, it can be concluded that the English learning using flash-based media improves the students' achievement.

Product developed by using flash-based has four aspects; those are (1) learning aspect, (2) contain aspect, (3) programming aspect, and (4) display aspect. The product of learning media is observed from each aspect indicator and has been in the valid category (Yusuf, 2015). The 
expert validation is the final result of the media before it is used in the process of teaching and learning. The media validation is after the stage of need analysis. The plan or the design of the product (prototype) which is developed is given to the team of the experts (validators), namely, the expert of media, material and practitioner. Based on the result from those experts, it is obtained the valid category.

The objective of the validation is to know whether the media can be used or not. So that, it is suggested to use in the step of trial test in the small and big group. In line with this view (Saselah, 2017) said, there is the positive result of using the flash-based media in the small and big scale. The appropriateness of media make the process of teaching and learning become active and efficient. So, it can be summarized that the appropriateness of the media in the current research is relevant with the previous research.

\section{The Effectivity of the Media}

The hypothesis test used in this research is paired-sample $t$ test. The level of significance is $\alpha=0,05$. The hypothesis test of paired-samplet-test: $H_{0}$ is rejected if the score of (Sig.) is $<0,05$ or $H_{0}$ is accepted if the score of (Sig.) is $>0,05$. The result of $t$ test can be seen in table 6 .

Table 6. paired-sample t-test of learning motivation

\begin{tabular}{cccc}
\hline Variable & Class & $\mathrm{N}$ & Sig (2-tailed \\
\hline Pre-test - Post-test & Experimental & 50 & .000 \\
Pre-test - Post-test & Controlled & 50 & .000 \\
\hline
\end{tabular}

Based on the table 6 , it shows that learning motivation in the experimental class is Sig.(2tailed) with the score of $0.00<0.05$ and the controlled class is Sig.(2-tailed) with the score of $000<0,05$. From that data, it can be concluded that the $H_{0}$ is rejected.

Table 7. Paired-Sample t-test of Students' Achievement

\begin{tabular}{clcc}
\hline Variable & Class & N & Sig (2-tailed \\
\hline Pre-test - Post-test & Experimental & 50 & .000 \\
Pre-test - Post-test & Controlled & 50 & .000 \\
\hline
\end{tabular}

Based on the table 7, the students' achievement for the experimental class is Sig.(2- tailed) with the score of $0.00<0.05$ and the Sig. (2-tailed) for the controlled class is $0.00<0.05$. From that result, it can be concluded that $H_{0}$ is rejected.

The effectivity of learning media gives the clarity of presenting and delivering the messages and information. Flash is the alternative way to help students' learning in the classroom and understand the material. It also is used as the learning resource for the students' (Juminah, 2019). One of the criteria in choosing the media is the media which support and relate to the contents of the material and it should be easy to get the media.

The final stage of the flash-based media development is the hypothesis test. The test is after the process of development and the appropriateness. Refer to the table 6 and 7, it can be concluded that the development of flash-based media in project-based learning for English subject is effective to improve and increase students' motivation and achievement at Senior High School.

The hypothesis test is to know the effectiveness of flash-based media. From the result, it is concluded that the media is effective enough to use. It is in accordance with (Alawiyah, 2014) there is the significant difference in writing learning before and after using the flash-based media. Supported by the research of (Listantia, 2015) the flash-based media is effective based on the minimum criteria of mastery learning (KKM) in the result or score of affective and psychomotor test. According to (Wardana, 2019) the flash-based media used in the problem-based learning improves the students' understanding during the process of teaching and learning. The material delivered using the flash-based media eases the students to comprehend the material, so that they achieve the learning objectives well. To sum up, that the result of the effectiveness test is relevant with the previous research.

\section{CONCLUSION}

Based on the development of the flashbased media for the descriptive text material, the 
need analysis shows that the teachers and students need the media using flash-based. The result of the media appropriateness from the media, material and practitioner expert gives the score with the very valid category. The result of the effectiveness of the students' motivation and achievement from the experimental and controlled class is Sig. (2-tailed) $<0.05$. So from that result, it can be concluded that the $H_{0}$ is rejected.

\section{REFERENCES}

Alawiyah, F. (2014). Kesiapan guru dalam implementasi kurikulum 2013. Jurnal Info Singkat, VI(15), 9-12. Retrieved from http://berkas.dpr.go.id/puslit/files/info sing kat/Info\%20Singkat-VI-15-I-P3DI-Agustus2014-56.pdf

Alawiyah, L. (2014). Developing Descriptive Writing Material Through Flash for Grade Seven in the Academic year of 2013/2014. English Education Journal, 4(1), 59-67. Retrieved from https://journal.unnes.ac.id/sju/index.php/eej /article/view/6646/4803

Budiani, S., Sudarmin, \& Syamwil, R. (2017). Evaluasi Implementasi urikulum 2013 di Sekolah Pelaksana Mandiri. Innovative Journal of Curriculum and Educational Technology, 6(53), 45-57. Retrieved from https://journal.unnes.ac.id/sju/index.php/uj et/article/view/15998

Chae, J., Cho, Y., Lee, M., Lee, S., Choi, M., \& Park, S. (2015). Design and implementation of a system for creating multimedia linked data and its applications in education. Multimedia Tools and Applications, 75(21), 13121-13134. Retrieved from https://doi.org/10.1007/s11042-015-2895-8

Farchan, A., \& Muhtadi, A. (2019). Pengembangan Desain Kurikulum Maritim di Jepara. Indonesian Journal of Curriculum and Educational Technology Studies, 7(1), 27-36. Retrieved from https://journal.unnes.ac.id/sju/index.php/jkt $\mathrm{p} /$ article/view/27973

Firdaus, F., \& Samsudi. (2012). Macromedia Flash Professional 8 sebagai Media Pembelajaran untuk Meningkatkan Prestasi Belajar Siswa. Jurnal Pendidikan Teknik Mesin, 12, 21-24. Retrieved from https://journal.unnes.ac.id/nju/index.php/JP $\mathrm{TM} /$ article/view/5272
Hutomo, B. P. M., \& Samsudi. (2015). Penerapan Media Interaktif Berbasis Macromedia Flash pada Kompetensi Dasar Memelihara Transmisi Otomatis dan Komponennya untuk Meningkatkan Hasil Belajar. Jurnal Pendidikan Teknik Mesin, 15(2), 78-81. Retrieved from https://journal.unnes.ac.id/nju/index.php/JP $\mathrm{TM} /$ article/view/9170

Jakab, I., Zigová, M., \& Zuzana, P. (2019). Modernization of Environmental Education with the Use of Project-Based Learning, Outdoor Education, and Mobile Learning Supported by Information and Communication Technology. Critical Studies of Education 10, 13, 223-248. Retrieved from https://doi.org/https://doi.org/10.1007/9783-030-05026-9 13223

Juminah, Sugiyo, \& Awalya. (2019). Information on Advanced Study Assisted by Adobe Flash Media to Increase Motivation for Advanced Studies. Jurnal Bimbingan Konseling, 8(1), 6773. Retrieved from https://journal.unnes.ac.id/sju/index.php/ju $\mathrm{bk} /$ article/view/27892

Kosam, D., Hardyanto, W., \& Haryono. (2018). Evaluative Survey of the Implementation of Curriculum 2013 for The English Subject in High School of South Buton District. Innovative Journal of Curriculum and Educational Technology, 7(2), 93-101. Retrieved from https://journal.unnes.ac.id/sju/index.php/uj et/article/view/29523

Lasauskiene, J., \& Rauduvaite, A. (2015). ProjectBased Learning at University: Teaching Experiences of Lecturers. Procedia - Social and Behavioral Sciences, 197(February), 788-792. Retrieved from https://doi.org/10.1016/j.sbspro.2015.07.182

Listantia, L., Sumarti, S. S., \& Prasetya, A. T. (2015). Pengembangan Media Pembelajaran Flash Berbasis Guided Discovery untuk Hasil Belajar Siswa. Chemistry in Education, 4(2252), 23-28. Retrieved from https://journal.unnes.ac.id/sju/index.php/ch emined/article/view/5410

Megawati, F. (2016). Kesulitan Mahasiswa dalam Mencapai Pembelajaran Bahasa Inggris Secara Efektif. Jurnal Pedagogia, 5(2), 147-156. Retrieved from http://ojs.umsida.ac.id/index.php/pedagogia /article/view/246

Molenda, M. (2003). In Search of the Elusive ADDIE Model. Performance improvement, 42(5). Submitted for publication in A. Kovalchick \& 
K. Dowson, Ed's, Educational Technology: An Encyclopedia. Copyright by ABC-Clio, Santa Barbara, CA. Retrieved from https://doi.org/10.1002/pfi.4930420508

Muyaroah, S., \& Fajartia, M. (2017). Pengembangan Media Pembelajaran Berbasis Android dengan menggunakan Aplikasi Adobe Flash CS 6 pada Mata Pelajaran Biologi. Innovative Journal of Curriculum and Educational Technology, 6(2301), 79-83. Retrieved from https://journal.unnes.ac.id/sju/index.php/uj et/article/view/19336

Nur, F. (2019). Evaluasi Isi/Materi Buku Teks Mata Pelajaran Sejarah Indonesia Kelas X Kurikulum 2013 Revisi 2017. Journal Of Multidisciplinary Research and Development, 1, 295-308. Retrieved from https://docplayer.info/137053043-Evaluasiisi-materi-buku-teks-mata-pelajaran-sejarahindonesia-kelas-x-kurikulum-2013-revisi2017.html

Palupi, D., \& Darmahusni. (2017). Pembelajaran Menulis Deskriptif Bahasa Inggris di Kelas Siswa Lamban Belajar (Suatu Kajian Etnografi di SMA Budi Waluyo, Jakarta) Dian. Jurnal Pendidikan Bahasa Dan Sastra, 16(3), 78-105. Retrieved from

http://journal.unj.ac.id/unj/index.php/bahte $\mathrm{ra} /$ article/view/4312

Permana, G. (2015). Pengembangan Model Pembelajaran Berbasis Masalah Menggunakan Software Macromedia Flash 8 pada Mata Pelajaran Instalasi Penerangan Listrik untuk Meningkatkan Hasil Belajar Peserta Didik di kelas XI TIPTL SMK Negeri 1 Nganjuk. Jurnal Pendidikan Teknik Elektro, 04(2), 1067-1073. Retrieved from https://jurnalmahasiswa.unesa.ac.id/index.p hp/jurnal-pendidikan-teknikelektro/article/download/13094/4766
Priyadana, M. I., \& Suharmono, A. (2015). Penerapan Media Berbasis Adobe Flash Professional CS5 untuk Meningkatkan Hasil Belajar Siswa pada Pembelajaran Kompetensi Rack Gear Lurus. Jurnal Pendidikan Teknik Mesin, 16(2), 96-100. Retrieved from https://journal.unnes.ac.id/nju/index.php/JP $\underline{\mathrm{TM} / \text { article/view/9168 }}$

Priyatni, Endah Tri. (2014). Desain Pembelajaran Bahasa Inggris dalam Kurikulum 2013. Jakarta: Bumi Aksara.

Rahmaibu, F. H., Ahmadi, F., \& Prasetyaningsih, F. D. (2016). Pengembangan Media Pembelajaran Menggunakan Adobe Flash untuk Meningkatkan Hasil Belajar PKN. Jurnal Kreatif, 1-10. Retrieved from https://journal.unnes.ac.id/nju/index.php/kr eatif/article/view/9362

Saselah, Y. R., Amir, M. M., \& Qadar, R. (2017). Pengembangan Multimedia Interaktif Berbasis Adobe Flash CS6 Professional pada Pembelajaran Kesetimbangan Kimia. Jurnal Kimia Dan Pendidikan Kimia, 2(2), 80-89. Retrieved from https://jurnal.uns.ac.id/jkpk/article/downloa d/11978/11918

Subekti, A., Yudha, S. S., \& Tri, H. B. L. (2016). Pemahaman dan Peran Guru TIK dalam Implementasi Kurikulum 2013 di Sekolah Menengah Atas. Indonesian Journal of Curriculum and Educational Technology Studies, 4(5), 25-31. Retrieved from https://journal.unnes.ac.id/sju/index.php/jkt $\mathrm{p} /$ article/view/14274

Yusuf, A. M. (2015). Pengembangan Media Pembelajaran Berbasis Adobe Flash untuk Mata Kuliah Fisika Modern Materi Radiasi Benda Hitam. Jurnal Sains Dan Pendidikan Fisika, 11, 57-71. Retrieved from https://ojs.unm.ac.id/JSdPF/article/view/14 $\underline{67 / 537}$ 